\title{
Failed promises of the cigarette industry and its effect on consumer misperceptions about the health risks of smoking
}

\author{
K M Cummings, C P Morley, A Hyland
}

Tobacco Control 2002;11(Suppl I):i1 10-i 117

Background: In January 1954, US tobacco manufacturers jointly sponsored an advocacy advertisement entitled "A Frank Statement to Cigarette Smokers" which appeared in 448 newspapers in 258 cities reaching an estimated 43245000 Americans. The advertisement questioned research findings implicating smoking as a cause of cancer, promised consumers that their cigarettes were safe, and pledged to support impartial research to investigate allegations that smoking was harmful to human health.

Objective: To examine (1) the extent to which cigarette companies fulfilled the promises made to consumers in the 1954 "Frank Statement", and (2) the effect of these promises on consumer knowledge, beliefs, and smoking practices.

Methods: This study reviews statements made since 1954 by the tobacco companies individually and collectively through the Tobacco Institute and Tobacco Industry Research Committee/Council for Tobacco Research on the subject of smoking as a cause disease, and the industry's pledge to support and disclose the results of impartial research on smoking and health. Many of the industry documents evaluated in this study were obtained from a collection consisting of 116 documents entitled the "Statement of Defendants' Misrepresentations" prepared by attorneys representing the state of Connecticut in the Medicaid litigation against the tobacco industry in 1998. In addition, we searched for corroborating material from tobacco industry documents collected from the tobacco industry's document websites. In order to contrast industry statements on smoking and health with what smokers' actually believed about smoking we reviewed reports of public polling data on smokers' knowledge and beliefs about smoking and disease gathered from tobacco industry sources and from surveys conducted by public health researchers.

Results: Analysis of public statements issued by the tobacco industry sources over the past five decades shows that the companies maintained the stance that smoking had not been proven to be injurious to health through 1999. The public statements of the tobacco industry are in sharp contrast to the private views expressed by many of their own scientists. The tobacco documents reveal that many scientists within the tobacco industry acknowledged as early as the 1950s that cigarette smoking was unsafe. The sincerity of the industry's promise to support research to find out if smoking was harmful to health and to disclose information about the health effects of smoking can also be questioned based upon the industry's own documents which reveal: (1) scepticism about the scientific value of the smoking and health research program established by the industry; and (2) evidence that research findings implicating smoking as a health problem were often not published or disclosed outside the industry. Industry documents also show that the companies knew that their own customers were misinformed about smoking and health issues.

Conclusion: It is clear that the cigarette companies failed to fulfill the promises made to consumers in the 1954 "Frank Statement" advertisement. The failure of cigarette manufacturers to honour these promises has resulted in a public that even today remains misinformed about the health risks of smoking.

New York 14263, USA;

Michael.Cummings@

Roswellpark.org

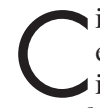
garette manufacturers have only recently acknowledged the medical and scientific consensus that smoking causes serious diseases such as lung cancer, respiratory disease and heart disease. ${ }^{1-6}$ For most of the past 100 years, cigarette manufacturers have told smokers that their products were not injurious to health. ${ }^{7-27}$ In fact, cigarette companies frequently promised consumers that their brands were better for them than their competitor's brands because the smoke was less irritating, smoother, and milder. ${ }^{27}$ In 1935 , RJ Reynolds told consumers that Camel cigarettes were so mild that "they don't get your wind" and that you could "smoke all you want". In 1943, Philip Morris told smokers" you're safer smoking Philip Morris ... this cigarette has been scientifically proved less irritating to the nose and throat ...eminent doctors report that every case of irritation of the nose and throat due to smoking cleared completely or definitely improved." In 1943, Lorillard promoted its Old Gold brand by claiming it was "lowest in nicotine, lowest in throat-irritating tars and resins." In 1946, Brown and Williamson used baseball legend Babe Ruth to pitch Raleigh cigarettes, with the claim that "Medical science offers proof positive ... No other leading cigarette is safer to smoke!" Ironically, Babe Ruth later died of throat cancer.

As publicity about the health risks of smoking increased in the 1950s the industry recognised that the design of products that were perceived by consumers to be safer could be profitable. For example, in 1953 one unnamed tobacco company research director was quoted as saying: "Boy, wouldn't it be wonderful if our company was the first to produce a cancer-free cigarette? What we could do to competition." ${ }^{28}$ In

Abbreviations: CTR, Council for Tobacco Research; FDA, Food and Drug Administration; RFP, request for production; $S A B$, scientific advisory board; TIRC, Tobacco Industry Research Committee 
the 1950s and 1960s, in response to information linking cigarette smoking with cancer, the tobacco industry propagated massive amounts of advertising that helped position filters and lower tar cigarettes as technological fixes. ${ }^{29} 30$

Product claims of less throat irritation, milder tasting smoke, and low tar and low nicotine were good selling points for cigarette brands as demonstrated by the increasing market share of filtered cigarettes in the 1950s and 1960s and later by the growth of low tar/low nicotine brands in the 1960s. ${ }^{31}$ Ironically, medical science has shown that making cigarette smoke milder, less irritating, and lower in nicotine increased smokers' ability to inhale the smoke into their lungs thereby negating any health benefit that might have been gained by altering the product. ${ }^{32-34}$ The question of when cigarette manufacturers should have known about the serious health consequences of smoking their products and what they told consumers about these risks is the crux of current litigation.

Evidence now indicates that senior scientists and executives within the cigarette industry knew about the cancer risks of smoking as early as the $1940 \mathrm{~s}^{35}$ and were aware that smoking could cause lung cancer by the mid 1950s. ${ }^{36}$ By 1961, cigarette companies had access to dozens of published scientific studies warning that cigarette smoking and chemical agents found in tobacco smoke might cause cancer. ${ }^{37}$ Despite growing knowledge of the serious health risks associated with cigarette smoking, cigarette companies continued to reassure smokers that their products were safe. In January 1954, Philip Morris, RJ Reynolds, Brown \& Williamson, Lorillard, and American Tobacco jointly placed an advertisement entitled "A Frank Statement to Cigarette Smokers" which appeared in 448 newspapers in 258 cities, reaching an estimated 43245000 people. ${ }^{78}$ The "Frank Statement" advertisement questioned research findings implicating smoking as a cause of cancer, promised consumers that their cigarettes were safe, and pledged to support impartial research to investigate allegations that smoking was harmful to human health. This paper examines the extent to which cigarette companies fulfilled the promises made to consumers in the 1954 "Frank Statement" advertisement and the effect of these promises on consumer knowledge, beliefs, and smoking practices.

\section{METHODS}

This study reviews statements made since 1954 by the tobacco companies individually and collectively through the Tobacco Institute and Tobacco Industry Research Committee/Council for Tobacco Research on the subject of smoking as a cause disease and the industry's pledge to support and disclose the results of impartial research on smoking and health. Many of the industry documents evaluated in this study were obtained from a collection consisting of 116 documents entitled the "Statement of Defendants' Misrepresentations" prepared by attorneys representing the state of Connecticut in the Medicaid litigation against the tobacco industry in 1998. ${ }^{39}$ In addition, we searched for corroborating material from tobacco industry documents collected from the tobacco industry's document websites. The websites were searched using "request for production" (RFP) codes, specified keyword searches, and serendipitous terms identified in document citations found with RFP and keyword searches.

In order to contrast industry statements on smoking and health with what smokers' actually believed about smoking we reviewed reports of public polling data on smokers' knowledge and beliefs about smoking and disease gathered from tobacco industry sources and by surveys conducted by public health researchers. ${ }^{40-51}$

\section{RESULTS}

\section{Promise 1: "We believe the products we make are not} injurious to health"

In October 1999, Philip Morris Tobacco Company announced to the public on its web site that "[t]here is an overwhelming medical and scientific consensus that cigarette smoking causes lung cancer, heart disease, emphysema and other serious disease in smokers."1 While some people may have interpreted this message to mean that Philip Morris had changed its long held position that smoking was not a cause of disease, in fact the message only acknowledged that there was medical and scientific consensus that smoking caused disease, not that Philip Morris accepted this consensus. A response from the Philip Morris board of directors to a shareholders' resolution on this subject revealed that the company had not changed it position about smoking and health. ${ }^{52}$ The shareholders' resolution asked the company to produce a report on how it intended to correct the defects that resulted in its products causing disease. A letter sent to the Securities and Exchange Commission, dated 10 February 2000, on behalf of Philip Morris responding to the proposed shareholders resolution noted that: "Mr Neuhauser's letter mischaracterizes the Company's web site as constituting a public admission that cigarettes causes illness. It does not.",25

The reality is that cigarette manufacturers have only recently-and in a very general way-acknowledged that smoking is a cause of lung cancer and other serious diseases. For example, in a recent interview, world scientific manager for Philip Morris, Bruce Davies, stated: "[Philip Morris] is not proud of the fact that our products cause disease." ${ }^{2}$ Other cigarette manufacturers have followed Philip Morris' lead in providing information to consumers about the risks of smoking and acknowledging that there is "no such thing as a safe cigarette." ${ }^{\prime-6}$ However, for the most of the past century, cigarette manufacturers have assured the public that the use of their products was safe.

The 1954 "Frank Statement" advertisement assured consumers that research into tobacco use and human health did not substantiate generalised charges against smoking as a cause of cancer. ${ }^{78}$ To help support the claim that their cigarette products were not injurious to health the Frank Statement advertisement informed the public that "distinguished authorities point out that there is no proof that cigarette smoking is one of the causes". ${ }^{738}$ However, this statement is misleading since some of the medical authorities identified as questioning the evidence that smoking was a cause of cancer did acknowledge that there might be some merit to the hypothesis, only that more research was needed. ${ }^{53} 54$

According to Edwin Jacobs, a lawyer who represented the tobacco industry, many industry officials in 1953 felt that claims about smoking and lung cancer were unsubstantiated and would eventually be proven false. ${ }^{55}$ Such beliefs may account for some of the bold promises and statements made by cigarette manufacturers around the time of the Frank Statement advertisement. For example, in a 1953 interview, Paul Hahn, president of the American Tobacco Company, stated: "[ $\mathrm{t}]$ here is no proof of lung cancer in any person traceable to tobacco or any form of tobacco product." ${ }^{1 /}$ In two 1954 speeches made by Philip Morris vice president George Weissman, he promised: "[I]f we had any thought or knowledge that in any way we were selling a product harmful to consumers, we would stop business tomorrow."' Company told stockholders: "[w]e believe Lorillard products are not injurious to anyone's health, but that we accept as an inherent responsibility of our corporate citizenship the obligation to make the public's health our business." ${ }^{10}$

Whether or not the top cigarette executives believed their own statements that smoking was safe, at least some of their scientists clearly thought otherwise. In 1953, a young chemist at RJ Reynolds', Dr Claude Teague, conducted a comprehensive literature survey on smoking and cancer in which he referenced 78 scientific papers on the topic of smoking and cancer. $^{36}$ Based on this comprehensive literature review, Teague concluded: "studies of clinical data tend to confirm the relationship between heavy and prolonged tobacco smoking and incidence of cancer of the lung. Extensive though inconclusive testing of tobacco substances on animals indicates the 
probable presence of carcinogenic agents in those substances." ${ }^{36}$ Teague was employed at RJ for Reynolds' for 35 years (1952-1987) and held various executive level positions at the company including that of director of research and development.

In 1956, a chemist who later also became the director of research at RJ Reynolds, Dr Alan Rodgman, commented on the implications of his research studies that had set out to isolate and/or identify several polycyclic aromatic hydrocarbons present in the cigarette smoke of Camel cigarettes. ${ }^{56}$ Rodgman stated in 1956 that: "[s]ince it is now well established that cigarette smoke does contain several polycyclic aromatic hydrocarbons and considering the potential and actual carcinogenic activity of a number of these compounds, a method of either complete removal or almost complete removal of these compounds from cigarette smoke is required." ${ }^{156}$ In a 1959 memo Rodgman noted that: "there is a distinct possibility that these substances [polycylic hydrocarbons] would have a carcinogenic effect on the human respiratory system." ${ }^{57}$ Scientists at RJ Reynolds were not the only ones acknowledging the probable association between smoking and cancer. A 1958 report authored by a British American Tobacco scientist who visited with leading industry and non-industry scientists in the USA and Canada, noted that: "with one exception the individuals whom we met believe that smoking causes lung cancer." ${ }^{\prime \prime 8}$ A 1961 Liggett and Myers memorandum stated that there are "biologically active materials present in cigarette tobacco. These are: a) cancer causing; b) cancer promoting; and c) poisonous." ${ }^{\prime 59}$ By 1978, a scientist at Lorillard acknowledged that: "[t]he [smoking] habit can never be safe." ${ }^{60}$

However, while internally acknowledging the mounting evidence showing a link between smoking and disease, cigarette manufacturers continued to deny the validity of the health charges against smoking externally. In 1957 speech to members of the Burley Auction Association, Philip Morris executive, George Weissman declared: "there is not one shred of conclusive evidence to support the link between cigarette smoking and lung cancer." ${ }^{\prime 11}$ In the 1959 annual report from Lorillard Tobacco, company chairman Lewis Gruber commented on new evidence pertaining to health in relation to tobacco by assuring stockholders that: "I believe in the innocence of our products as well as their future."11 A 1963 letter to an elementary school teacher from RJ Reynolds Tobacco Company assured the teacher that: "medical science has been unable to establish that smoking has a direct causal link with any human disease."12

Even after the Surgeon General issued his report on smoking and health in 1964, cigarette companies continued to cast doubt on the link between smoking and cancer. A 1968 Tobacco Institute publication entitled "The Cigarette Controversy" stated "no scientific proof, then, has been found to convict smoking as a hazard to health."13 A 1969 advertisement published in the New York Times by the American Tobacco Company proclaimed: "[w]e believe the anticigarette theory is a bum rap."14

In 1971, the chairman of Philip Morris, Joseph Cullman, appeared on the TV news show, Face the Nation, and declared: "we do not believe that cigarettes are hazardous; we don't accept that."15 In 1972 interview with the Wall Street Journal, Philip Morris vice president James Bowling repeated the company's promise to consumers two decades earlier that "if our product is harmful, we'll stop making it."'16 Bowling repeated the company's position on smoking and health in a 1976 interview when he noted: "from our standpoint, if anyone ever identified any ingredient in tobacco smoke as being hazardous to human health or being something that shouldn't be there, we could eliminate it. But no one ever has.." ${ }^{17}$ In a 1976 letter sent to an individual who had written a letter to the RJ Reynolds Tobacco Company after his father had been diagnosed with lung cancer, the company responded that: "this Company does not regard itself as being in any way responsible. We firmly believe that cigarettes have been unfairly blamed as a cause of human disease." ${ }^{18}$ In a 1978 magazine interview William Dwyer, vice president of the Tobacco Institute, stated: "we take the view that the best science can say is that cigarette smoking may be hazardous. And then it may not be."19 A 1978 Philip Morris publication entitled "Facts About the Smoking Controversy" stated: "scientists have not determined what causes cancer . . . cigarettes have never been proven unsafe." ${ }^{20}$

Throughout the 1980s and 1990s the cigarette industry held fast to the view that scientists had not proven conclusively that smoke or any of the thousands of its constituents as found in cigarette smoke causes human disease. A 1990 letter sent by RJ Reynolds to the principal of an elementary school in upstate New York declared: "[d] espite all the research going on, the simple and unfortunate fact is that scientists do not know the cause or causes of the chronic diseases reported to be associated with smoking." ${ }^{21}$ The letter encouraged the school principal to share this information with his fifth grade students. In the 1994 Congressional hearing before the Subcommittee on Health and the Environment, industry executives again expressed their belief that smoking had not been proven to be a cause of cancer. ${ }^{22}$ As recently as 1998, a senior research scientist at RJ Reynolds testified that: "[I]t's not scientifically established that smoking by itself causes disease." ${ }^{23}$ In 1998, Philip Morris chairman Geoffrey Bible responded to the question "has anyone died from smoking cigarettes?" in the following manner: "I don't know if anyone dies from smoking tobacco, I just don't know." ${ }^{24}$

\section{Promise 2: "We are pledging aid and assistance to the research effort into all phases of tobacco use and health"}

The 1954 "Frank Statement" advertisement promised the public that the tobacco industry would support research into all phases of tobacco use and health. ${ }^{73}$ Towards this end, the tobacco industry announced the establishment of the Tobacco Industry Research Committee (TIRC), which later became known as the Council for Tobacco Research (CTR). The stated goal of the TIRC was "to investigate and make known to the public facts about tobacco use in relation to human wellbeing." ${ }^{22}$ According to a 1957 TIRC press release: "[o]ur sole purpose is to encourage and support qualified research scientists in their efforts to learn more about these complex problems [cancer and heart disease]." ${ }^{63}$ However, many TIRC and CTR funded research projects were only remotely related to smoking and health, as acknowledged in a 1960 court case (the Lartique trial) by the first scientific advisory board (SAB) chairman of TIRC, Dr Clarence Cook Little. ${ }^{64}$ Little "testified that TIRC had conducted no studies of tobacco smoke because it had never been proven to be carcinogenic. He viewed such a study a waste of time. Similarly, Little refused to conduct animal experimentation because he believed that it was only relevant to animals, not human beings. Finally, TIRC did not sponsor epidemiological studies." ${ }^{\prime 64}$ Evidence that CTR funded research projects had little to do with smoking and health was further confirmed in a 1989 survey of CTR funded scientists, which asked grantees if their research had anything to do with understanding the relationship between smoking and health. Only one of six scientists responded affirmatively to this question. ${ }^{65}$

While the tobacco industry touted the SAB "independence" to determine what research was deemed worthy of supporting, the SAB was selected by the tobacco companies. It is noteworthy that no person known to favour the cigarette/ disease hypothesis was selected to serve on the original SAB. ${ }^{64}$ The independence of the TIRC/CTR can also be questioned by the amount of money disbursed either directly to the chair of the $\mathrm{SAB}$ and to $\mathrm{SAB}$ members themselves or to the institutions with which they were affiliated. ${ }^{64}$ Two board members, Dr Richard Bing and Dr Hans Meier, received grants from the TIRC/CTR each of the years they served on the $\mathrm{SAB}^{64}{ }^{64}$ The independence of the TIRC/CTR was even questioned by the president of American Tobacco Company (RK 
Heiman) who in 1977 wrote: "Another side result of our new direction is that we seem to be combining in one person, a Scientific Director and a quasi-grantee, a combination which is hardly compatible with the administration of an objective and independent grant program." ${ }^{64}$

Internal industry documents also reveal that industry scientists questioned the scientific value of research produced by the TIRC/CTR. For example, the director of research for Philip Morris said in 1970 that: "[I]t has been stated that CTR is a program to find out the truth about smoking and health. What is truth to one is false to another. CTR and the Industry have publicly and frequently denied what others find as truth. Let's face it. We are interested in evidence which we believe denies the allegation that cigarette smoking causes disease." ${ }^{\prime 66}$ Notes from a 1978 meeting of the officials of the major tobacco companies to discuss the future role of the CTR reveals that CTR was considered valuable primarily for public relations purposes ${ }^{67}$

Despite the fact that much of the research supported by the tobacco industry had little to do with understanding the health effects of smoking, cigarette companies publicised their support of scientific research as a way to reassure the public that an answer to the question of whether smoking caused disease would be forthcoming. For example, a 1958 press release from the Tobacco Institute declared that: "[ $\mathrm{t}]$ he industry itself is contributing millions through unbiased scientific research facilities to find the truth.." ${ }^{68}$ In a 1957 magazine article authored by Clarence Little, director of the TIRC, he wrote that: "[t]he industry intends to support research until these charges can be proved or disproved by direct experimental evidence." $^{\prime 69}$ A 1962 press release from the Tobacco Institute reassured the public that: "[w]e in the tobacco industry recognize a special responsibility to help science determine the facts." ${ }^{70}$ In a 1966 speech by Philip Morris president Joseph Cullman to members of the South Carolina Tobacco Warehouse Association, he stated: "We feel a deep sense of responsibility to our cigarette smokers . . We intend to leave no research question unanswered in our quest for the truth." ${ }^{171}$ In a 1976 letter from RJ Reynolds to the family member of a lung cancer patient, Reynolds noted: "[y]ou may be interested in knowing that we and others in our industry have for many years supported scientific research to learn the true facts about smoking and health."18 In 1985, RJ Reynolds took out advertisements in major newspapers and magazines which stated: "We believe in science. That is why we continue to provide funding for independent research into smoking and health ... Science is science. Proof is proof. That is why the controversy over smoking and health remains an open one."72 A 1990 letter from the RJ Reynolds Tobacco Company to an elementary school principal stated that: "the tobacco industry in a sincere attempt to determine what harmful effects, if any, smoking might have on human health, established the Council for Tobacco Research - USA."21

During its four decade history the TIRC/CTR never acknowledged that smoking had been proven to be a cause of cancer or other serious diseases in smokers, even though the vast majority of CTR funded scientists themselves believed that cigarette smoking was responsible for a wide range of serious, and often, fatal diseases. ${ }^{65}$ It appears that the cigarette companies were unwilling to accept the opinions of the scientists it had deemed worthy to support. More striking is the fact that during the same period when cigarette companies expended billions of dollars to design and market cigarette brands that ostensibly lowered a smoker's exposure to the harmful constituents in tobacco smoke, research on the health benefits of these redesigned products was virtually nonexistent. ${ }^{29} 73$

Promise 3: "We always have and always will cooperate closely with those whose task it is to safeguard the public health"

The 1954 "Frank Statement" advertisement told the public that the tobacco industry "will cooperate closely with those whose task it is to safeguard the public health." ${ }^{78}$ However, rather than cooperate, there is abundant evidence that the tobacco industry went to great lengths to undermine tobacco control efforts of the public health community. The former director of the US Food and Drug Administration (FDA), Dr David Kessler, has recently described the efforts of the industry to avoid regulation by the FDA. ${ }^{74}$ Other recent publications have also documented how Philip Morris, RJ Reynolds, and Brown \& Williamson attempted to thwart public health efforts to curb tobacco use. ${ }^{75-77}$ Additionally, it is clear that the tobacco industry has endeavoured to influence or undermine specific tobacco control efforts and credibility of public health officials. ${ }^{78}{ }^{79}$ A 1972 Tobacco Institute memorandum from vice president Fred Panzer to Tobacco Institute president Horace Kornegay describes the industry's strategy "for nearly twenty years" consisted of "creating doubt about the health charge without actually denying it"; "advocating the public's right to smoke, without actually urging them to take up the practice"; and "encouraging objective scientific research as the only way to resolve the question of the health hazard." ${ }^{80}$ The document describes that although this strategy had been effective in litigation and "on the political front" it was rapidly becoming a public relations failure. Panzer stressed: "the public . . .must perceive, understand, and believe in evidence to sustain their opinions that smoking may not be the causal factor in lung cancer. As things stand, we supply them with too little in the way of ready made credible alternatives." ${ }^{\prime 0}$ He then points out "two such credible alternatives exist": the "constitutional hypothesis" that smokers differ in substantive ways from non-smokers; and the "multifactoral hypothesis" that "as science advances, more and more factors come under suspicion as contributing to the illnesses for which smoking is blamed . . ." ${ }^{80}$ Panzer goes on to outline a plan to disseminate such information in a believable manner to the public. Other documents indicate that such research was supported by the tobacco industry. ${ }^{81}$

The 1954 "Frank Statement" advertisement also told the public that the tobacco industry had "an interest in people's health as a basic responsibility, paramount to every other consideration in our business." ${ }^{138}$ The goal of supporting research on smoking and health was, the companies claimed, to find out if their products posed a health hazard and then to share this information with consumers. In 1955, the director of the TIRC, Dr Clarence Cook, did a TV an interview with Edward R Murrow in which he was asked the following question: "Suppose the tremendous amount of research going on were to reveal that there is a cancer-causing agent in cigarettes, what then?" Little replied: "[I]t would be made public immediately and just as broadly as we could make it, and then efforts would be taken to attempt to remove that substance or

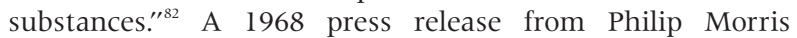
declared: "[w]e would like the public to be fully informed." ${ }^{83} \mathrm{~A}$ 1970 advertisement from the Tobacco Institute said: "[t]he Tobacco Institute believes the American public is entitled to complete, authenticated information about cigarette smoking and health." ${ }^{84}$

Despite the promise made to disclose information about smoking and health issues to the public, internal industry documents reveal that cigarette companies failed to keep this promise. A 1953 document from the files of the public relations firm of Hill and Knowlton which helped create the TIRC, suggests that the purpose of the "Frank Statement" advertisement was to assure smokers that it was safe to smoke rather than to share what was known about the health dangers of smoking: "There is only one problem-confidence, and how to establish it; public assurance, and how to create it . . And, most important, how to free millions of Americans from the guilty fear that is going to arise deep in their biological depths-regardless of any pooh-poohing logic-every time they light a cigarette."28 A 1962 internal report on the "smoking and health problem", written by RJ Reynolds scientist Dr 
Table 1 Misperceptions about smoking reported in recent surveys

\begin{tabular}{lllll}
\hline $\begin{array}{l}\text { Date of } \\
\text { survey }\end{array}$ & Reference & Survey method and sample & Knowledge/belief question & Response to question \\
\hline 1994 & 48 & $\begin{array}{l}\text { Nationwide telephone survey of } \\
335 \text { current and recent ex-smokers }\end{array}$ & $\begin{array}{l}\text { "Do you know the tar level of the } \\
\text { cigarette you smoke?" }\end{array}$ & $79 \%$ said no
\end{tabular}

$1995 \quad 47 \quad$ Nationwide telephone survey of 737 current smokers

$1996 \quad 46$

1997

50

2001

"Do you think your risk of a myocardial Only $29 \%$ and $40 \%$ of smokers believed they infarction (or cancer) is higher, the same, have a higher average risk of myocardial or lower than other (men/women) your infarction or cancer, respectively age?"

"Do "Does your current brand Telephone survey of 142 Light and Ultra light cigarette smokers in Massachusetts

In-person intercept survey of a convenience sample of 52 current and 24 former smokers.

"Do you think a filter makes a cigarette safer than the same cigarette without a filter?

Nationwide telephone survey of 1046 current smokers cigarette smoking less dangerous?
"Has the addition of filters made "Has the reduction of tar in made cigarette smoking less dangerous?" 
fully accepted the proposition that smoking cigarettes is dangerous to health" and that "the American public is presently uninformed [about smoking] by almost any definition of informed." ${ }^{44}$ Evidence from recent surveys of smokers' knowledge and beliefs, as summarised in table 1, suggests that smokers continue to be misinformed about smoking. . $^{4-48} 5051$ Cohen reported results of a national probability telephone survey, in which he found that few smokers knew the tar levels of their own cigarettes and most did not know how to interpret the tar ratings. ${ }^{48}$ Filter vents are key to reducing the standard tar and nicotine yields of cigarettes. All Ultra Light ( $1-5 \mathrm{mg}$ tar) and Light brands (6-15 $\mathrm{mg}$ tar) of cigarettes have ventilated filter tips. Vent blocking during smoking will increase the amount of tar the smoker will be exposed to. Thus, it is important for smokers to be aware of the filter vents in their cigarettes so they are not blocked during smoking. Kozlowski and colleagues found that few Massachusetts cigarette smokers were aware of the filter vents in their cigarettes. ${ }^{46}$ Hastrup and colleagues recently reported the results of a convenience survey of 52 current and 24 former smokers, which found that $58 \%$ incorrectly believed that the addition of a filter would make the cigarette safer. ${ }^{50}$ Cummings found a similar result from a nationwide sample of 1046 smokers who were asked whether the addition of filters or the reduction of tar levels in cigarettes has made smoking safer. ${ }^{51}$ Finally, Ayanian and Cleary reported the results of a 1995 nationwide survey, which found that $30-40 \%$ of smokers failed to acknowledge their higher average risk of heart disease and cancer caused by smoking. ${ }^{47}$ Previous reviews of industry documents related to the marketing of low tar cigarettes have demonstrated an awareness on the part of the cigarette companies that smokers did not appreciate that switching to a low tar cigarettes was no safer than smoking a regular cigarette because of compensatory smoking (that is, puffing harder, smoking more of each cigarette, smoking more cigarettes per day)..$^{29} 90$

\section{DISCUSSION}

The cigarette companies that signed the 1954 "Frank Statement" did not fulfill the promises made to the public in that advertisement. Cigarette smoking is clearly injurious to health, a fact that cigarette companies have only very recently begun to acknowledge to the public. ${ }^{2}$ However, the question remains as to when the cigarette companies could have known that their products posed a serious risk to their consumers.

The tobacco documents show that the cigarette companies were carefully monitoring the scientific literature on smoking and health before 1950, and that at least some of their scientists recognised that cigarette smoking was unsafe by the mid 1950s. The conclusion reached by Reynolds' scientist Claude Teague in 1953, that long term heavy smoking was a health risk, is reflected in the writings of other industry scientists during the later part of the 1950s and subsequently. For example, a decade following Teague's 1953 report, RJ Reynolds scientist Dr Alan Rodgman characterised the amount of evidence accumulated to indict cigarette smoking as a health risk as "overwhelming" while the evidence challenging such an indictment was "scant". ${ }^{53}$

The failure of cigarette manufacturers to honour the promises made in the "Frank Statement" has contributed to a public that even today remains misinformed about the tobacco products that they consume..$^{46-517391}$ Notwithstanding the cigarette companies' demonstrated expertise in advertising and marketing, and the extraordinary financial resources at their disposal, the companies have not even been successful in communicating to consumers their newfound belief that cigarette smoking is hazardous. Nearly $60 \%$ of smokers in a recent (2001) nationwide poll agreed with the statement: “[c]igarette companies still do not believe that smoking can cause cancer". ${ }^{51}$ Misperceptions about the relative health risks of

\section{What this paper adds}

This paper provides an analysis of the extent to which the promises made to the American public by the tobacco industry in the infamous "Frank Statement to Cigarette Smokers" were fulfilled. While most of the industry documents reviewed in this paper have been uncovered previously, an analysis of these documents in terms of the Frank Statement promises, and the industry's record of not carrying them out, is new. This paper should prove to be a very important tool for tobacco litigation, since the Frank Statement has been a centerpiece of most of the cases, which have involved exposing the industry's bad faith at the very beginning, failure to comply thereafter, and the resulting misinformation among the consuming public.

cigarettes, smokeless tobacco products, and nicotine medications may prevent smokers from switching from cigarettes to less dangerous forms of nicotine delivery. ${ }^{73}$ Cigarette companies should be held accountable for making sure that persons using their products are adequately informed about the health risks involved.

\section{ACKNOWLEDGEMENTS}

The research described in this paper was supported by grants from the National Cancer Institute CA77021-03, CA87696-01, and by Core Grant CAl6056-26.

\section{Authors' affiliations}

K M Cummings, C P Morley, VA Hyland, Department of Cancer Prevention, Epidemiology \& Biostatistics, Roswell Park Cancer Institute, Elm and Carlton Streets, Buffalo, New York 14263, USA

\section{REFERENCES}

1 http://www.philipmorrisusa.com/DisplayPageWithTopic. asp?ID=60

2 Interview with David Davies, Philip Morris. BBC Hard Talk, 29 March 2001.

3 British American Tobacco. Smoking - our view. Detailed smoking and health messages (for internal use only), May 2001

4 http://www.bw.com/Index_sub2.cfm? ID = 1

5 http://www.rirt.com/Tl/Pages/TIHealth_Issues.asp

6 http://cnnfn.com/1998/04/28/companies/liggett/

7 Tobacco Industry Research Committee (TIRC). A Frank Statement to Cigarette Smokers. 4 January 1954. Bates No. 03046592-03046593.

8 Paul Hahn issues reassurance on cigarettes' use. United States Tobacco Journal. 30 November 1953. Bates No. MNAT 00016506-00016507.

9 Weissman, George, Philip Morris Inc. Facts versus fancy. 26 February 1954. Bates No. 1002366389-1002366397; see also Weissman, George, Philip Morris Inc. Public relations and cigarette marketing. 30 March 1954. Bates No. 1002366398-1002366402.

10 P Lorillard Company. P Lorillard Company Annual Report 1953. 31 December 1953. Bates No. 93224668-93224693.

11 P Lorillard Company. P Lorillard Company Annual Report 1959. 31 December 1959. Bates No. 81215878-81215894.

12 Mann J P. R.J. Reynolds Tobacco Co. [Letter to 4th grade students]. 1 May 1963. Bates No. 500670688

13 The Tobacco Institute. The Cigarette Controversy: An examination of the facts by The Tobacco Institute. 01/01/68. Bates No. TIMN 0104765-0104868

14 The American Tobacco Co. Why we're dropping the New York Times 4 September 1969. The New York Times. Bates No. 500011469.

15 Herman G, Cullman J, Mintz M, et al. Transcript: Face the Nation. 3 January 1971. Bates No. 1002605545-1002605564.

16 Kwitny Jonathan. Defending the weed: how embattled group uses tact, calculation to blunt its opposition. The Wall Street Journal. January 24 , 1972. Bates No. $500324162-500324164$.

17 Bowling, JC, Taylor P. This week: Philip Morris: Mr James C Bowling, vice president, Philip Morris Inc being interviewed by Mr Peter Taylor, Thames Broadcasting Co, London. 16 August 1976. Bates No. 1002410318-1002410351.

18 Cahill TK. R. J. Reynolds Tobacco Co. [Letter to James T. Accardo], 26 March 1976. Bates No. 500320855

19 Trisler S, Nation J. The Tobacco Institute. Interview with William F. Dwyer. November 1978. Bates No. TIMN 0079009-0079016.

20 Philip Morris. Facts about the smoking controversy. 1 March 1978 Bates No. WA $2023200631-2024299643$

21 Spach JF. R.J. Reynolds Tobacco Co. [Letter to Willow Ridge Schoo principal]. 11 January 1990. Bates No. 508466199-508466200. 
22 Hearing before the Subcommittee on Health and the Environment of the Committee on Energy and Commerce. 1994. State of Connecticut vs. Philip Morris, Inc. et al. Statement of defendants' misrepresentations. July 1998. Tab \#61.

23 Testimony by David Townsend, VP for Product Development and Assessment, RJR. Minnesota vs. Philip Morris et al, 2 April 1998.

24 Geyelin M. Tobacco executive doubts product risks. Wall Street Journal 1998

25 Whitson J. Jerry, Hunton \& Williams. [Letter to Securities and Exchange Commission on behalf of Philip Morris regarding] Shareholder proposa submitted by Gregory N Connolly. 10 February 2000.

26 Prosecution Memorandum: Requesting a formal investigation by the United States Department Of Justice of the possible violation of federal criminal laws by named individuals and corporations in, or doing business with, the tobacco industry. Submitted by US Rep. Martin T Meehan to US Attorney General Janet Reno, 14 December 1994. http://www.stic.neu.edu/MN/6MMMEMO. HTM

27 See historical archive of over $\mathbf{8 0 0 0}$ examples of cigarette brand advertising at http://roswell.tobaccodocuments.org /click on the Richard W. Pollay 20th Century Tobacco Advertisement Collection)

28 Forwarding Memorandum Hill Archives. 1 December 1953. Bates No. JH 000493 -JH 000501. MN Trial Exhibits TE 18904

29 Pollay RW, Dewhirst T. The dark side of marketing seemingly "Light" cigarettes: successful images and failed acts. Tobacco Control 2002;11 (suppl I):i18-31.

30 Swedrock T, Hyland A, Hastrup JL. Changes in the focus of cigarette advertisements in the 1950's. [letter]. Tobacco Control 1999;8:111-12.

31 Maxwell JC, Jr. Historical sales trends in the cigarette industry: a statistical summary covering 69 years (1925-93). 1994. Richmond Virginia, Wheat, First Securities, Inc.

32 Djordjevic $\mathbf{M}$, Stellman SD, Zang E. Doses of nicotine and lung carcinogens delivered to cigarette smokers. J Ntl Cancer Inst 2000;92:106-11.

33 Burns DM, Benowitz NL (eds). Smoking and Tobacco Control Monograph 13: Risks associated with smoking cigarettes with low machine-measured yields of tar and nicotine. Washington DC: Nationa Cancer Institute, 2001

34 Kozlowski LT, O'Connor RJ. Cigarette filter ventilation is a defective design because of misleading taste, bigger puffs, and blocked vents. Tobacco Control 2002; 11 (suppl I):i40-50.

35 Jones, Day, Reavis \& Pogue. Fact Team Memorandum. 31 December 1985. Bates No.: 515873805-515873929.

36 Teague C. Survey of cancer research. R. J. Reynolds Tobacco Co. 2 February 1953. Bates No. 501932947-501932968.

37 Larson PS, Haag HB, Silvette H. Tobacco. Experimental and clinical studies. Baltimore, Maryland: Williams and Wilkens, 1961.

38 Pollay RW. Propaganda, puffing and the public interest: the scientific smoke screen for cigarettes. Public Relations Review 1990;16:27-42

39 State of Connecticut vs. Philip Morris, Inc. et al. Statement of defendants' misrepresentations. 1 July 1998

40 Moore D.E. Nine of ten Americans view smoking as harmful. Gallup Organization, 7 October 1999

41 Saad L, O'Brien S. The tobacco industry summons polls to the witness stand: a review of public opinion on the risks of smoking. Paper presented at the annual meeting of The American Association for Public Opinion Research, St Louis, Missouri, 15 May 1998

42 Elmo Roper and Associates. Volume 1: A study of attitudes toward cigarette smoking and different types of cigarettes. January 1959.

43 Hall LW, Jr. Consumer research report. Cigarette "substitute" concept study. R.J. Reynolds Tobacco Company, 20 May 1970 Bates No. 501001796-501001857

44 Fishbein $M$. Consumer beliefs and behavior with respect to cigarette smoking: a critical analysis of the public literature. Report prepared for the Federal Trade Commission, May 1977.

45 US Department of Health and Human Services. Reducing the health consequences of smoking: 25 years of progress. A report of the Surgeon General, 1989. Rockville, Maryland: Public Health Service, Centers for Disease Control, Office on Smoking and Health, 1989. (DHHS Publication No (CDC) 89-8411.)

46 Kozlowski L, et al. Few smokers know their own cigarettes have filter vents. Am J Public Health 1998;88:861-82.

47 Ayanian JZ, Cleary PD. Perceived risks of heart disease and cance among cigarette smokers. JAMA 1999;281:1019-21

48 Cohen JB. Smokers' knowledge and understanding of advertised tar numbers: health policy implications. Am J Public Health 1996:86:18-24.

49 Slovic P. Smoking: risk, perception \& policy. Thousand Oaks, California: Sage Publications, Inc, 2001.

50 Hastrup JL, Cummings KM, Swedrock T, et al. Consumers' knowledge and beliefs about the safety of cigarette filters [letter]. Tobacco Control $2001 ; 10: 84$

51 Cummings KM. Do smoker's really understand the risks of smoking? Unpublished findings from a nationwide survey of current cigarette smokers. Roswell Park Cancer Institute, 1 September 2001.

52 Bible G. Notice of annual meeting of stockholders and proxy statements. Philip Morris Companies, Inc, 10 March 2000.

53 Rodgman A. A critical and objective appraisal of the smoking and health problem. R.J. Reynolds, 1962, Bates No. 504822823-504822846

54 Pollay RW, Dewhirst TE. The unscientific perspective of the Tobacco Industry Research Committee [1954]. University of British Columbia History of Advertising Archives, Working Paper 98.5, August 1998

55 Tursi F, White SE, McQuilkin S. Lost empire. Chapter 4: manning the ramparts-health charges begin to affect cigarette sales, and tobacco agrees to speak with one voice. Winston-Salem Journal 31 October 1999
56 Rodgman A. The analysis of cigarette smoke condensate. I. The isolation and/or identification of polycyclic aromatic hydrocarbons in Came cigarette smoke condensate. R. J. Reynolds Tobacco, 28 September 1956, Bates No. 504912057-504912091.

57 Rodgman A. The optimum composition of tobacco and its smoke. R. J. Reynolds Tobacco, 2 November 1959. Bates No. 500945942-500945945

58 Bentley HR, Felton DGI, Reid WW. Report on visit to USA and Canada. 12 May 1958. Minnesota TE 11028.

59 Arthur $\mathbf{D}$ Little, Inc, Liggett \& Meyers. L \& M - A perspective review. 15 March 1961. Bates No. 2021382496-2021382498.

60 Conning DM. The concept of less hazardous cigarettes. 15 May 1978. Bates No. 01414847-014148853.

61 Weissman G. Speech to the Burley Auction Warehouse Association. Cumberland Falls, Kentucky, 27 May 1957. Bates No. 1002366508-1002366519

62 Hill \& Knowlton, Inc. For: Tobacco Industry Research Committee. For immediate release 12 October 1954. CTR public statement 000101

63 Hill \& Knowlton, Inc. For: Tobacco Industry Research Committee. Hartnett cites points for clarification in tobacco health study. For immediate release 23 March 1957. CTR public statement $000312-000314$

64 Jones, Day, Reavis \& Pogue. Untitled. Bates No. $681879254-681879715$

65 Cummings KM, Sciandra A, Gingrass, et al. What scientists funded by the tobacco industry believe about the hazards of smoking. Am J Public Health 1991;81:894-5.

66 Wakeham H. "Best" Program for C.T.R. 8 December 1970. 2022200161-2022200163.

67 Memorandum from Philip Morris Employee (R.B. Seligman) to Philip Morris Counsel (A. Holtzman). Subject: Meeting in New York, 17 November 1978. Bates No. 1003718428-1003718433.

68 Hill \& Knowlton, Inc. The Tobacco Institute, Inc. For Release: In PM's of Tuesday, 1 July 1958. ST 3-0270. Bates No. 1005036790-1005036791.

69 Little CC. Council of Tobacco Research. The public and smoking December 1957. CTR public statement 000368-000371

70 Allen G. The Tobacco Institute. The tobacco economy - 1962 review and outlook. 27 December 1962. Bates No. WA 1005136953-1005136957.

71 Cullman, JF 3rd. Remarks of Joseph G Cullman, 3rd - President-Philip Morris, Inc. The South Carolina Tobacco Warehouse Association Inc. Myrtle Beach, South Carolina. 7 June 1966. Bates No. $002600012-002600023$

72 RJ Reynolds. Of cigarettes and science. 25 March 1985. Bates No. 513960251

73 Stratton K, et al. Clearing the smoke: assessing the science base for tobacco harm reduction. Washington DC: National Academy Press, 2001.

74 Kessler D. A question of intent: a great American battle with a deadly industry. New York: Public Affairs, 2001.

75 Kluger R. Ashes to ashes: America's hundred-year cigarette war, the public health, and the unabashed triumph of Philip Morris. New York: Alfred A Knopf, 1996

76 Tursi F, White SE, McQuilkins S. The ax falls Surgeon General's 'experts' find a smoking-cancer link and the FTC sets up hearings on requiring warning labels; stunned cigarette-makers rally together in self-defense. Winston-Salem Journal. 7 November 1999.

77 Glantz SA, Slade J, Bero LA, et al. The cigarette papers. Berkeley, California: University of California Press, 1996.

78 Morley C, Cummings KM, Hyland A, et al. Tobacco Institute lobbying at the state and local levels of government in the 1990s. Tobacco Control 2002; 11 (suppl I):i 102-9.

79 See http://www.library.ucsf.edu/tobacco/state.html for reports by Glantz et al on the activities of the tobacco industry to influence and undermine tobacco control.

80 Panzer F. Subject: the Roper proposal. Philip Morris Incorporated. The Tobacco Institute. 1 May 1972. Bates No. Range: 2024274199-2024274202. http://www.pmdocs.com.

81 Lincoln JE. Subject: additional thoughts on the constitutional theory. Philip Morris Incorporated. 31 July 1972. Bates No. 1003035041-1003035042. http://www.pmdocs.com.

82 Murrow ER, Hueper WC. Selected excerpts from Edward R. Murrow's TV Program on cigarettes and lung cancer. 31 May 1955. WIH $00001485-00001500$

83 Ruder \& Finn Incorporated for Philip Morris. Press release: Major tobacco company executive says that "care, cooperation and confidence" will provide acceptable answers to smoking and health controversy. 28 October 1968. Bates No. 1002367358-1002367362.

84 The Tobacco Institute. The Tobacco Institute believes the American public is entitled to complete, authenticated information about cigarette smoking and health. The American Cancer Society does not seem to agree. 1970. Bates No. 2023038910.

85 http://outside.cdc.gov:8085/BASIS/shd/shdview/smoking/SF.

86 Spencer T. Engle: Doctor targets tobacco company's claims. Sun-Sentinel.com 3 November 1999 (see quote from attorney Dan Webb representing Philip Morris: "To say he [Frank Amodeo] was not aware of the dangers of cigarette smoking since that time [1964] is silly"); also see: Spencer T. Another Big Tobacco CEO admits cigarettes addictive, cause cancer. Sun-Sentinel.com 14 June 2000 (see quote from Nicholas 
G Brookes, chairman and CEO of Brown and Williamson: "We believe that the risks are known to smokers"); also see: Herzog B, Lotts M. Anderson trial verdict. Credit Suissee/First Boston, 27 June 2000 ("The defendants argued that $\mathrm{Mr}$ Anderson was well aware of the dangers of smoking.").

87 Kessler DA. Statement on nicotine-containing cigarettes. Testimony before House Subcommittee on Health and the Environment, March 25, 1994. Tobacco Control 1994;3: 148-58.

88 US Department of Health and Human Services. The health consequences of smoking: nicotine addiction. A report of the Surgeon General, 1988. Rockville, Maryland: Public Health Service, Centers for
Disease Control, Office on Smoking and Health, 1988. (DHHS Publication No (CDC) 88-8406.)

89 US Food and Drug Administration. 21 CFR Part 801, et al Regulations restricting sale distribution of cigarettes and smokeless tobacco products to protect children and adolescents; Final Rule. Federal Register 1995 (11 August); 60(155):41314-41375, $41453-41787$

90 Leavell NR. Low tar lie. Tobacco Control 1999;8:433-6.

91 Schoenbaum $\mathbf{M}$. Do smokers understand the mortality effects of smoking? Evidence from the Health and Retirement Survey. Am J Public Health 1997:87:755-9.

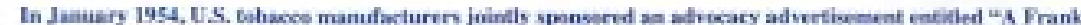
Stalement in Cigarette Smakers" which appeared in 448 newspegers in 258 cities reaching an estimated $43,245,1000$ Americans.

\section{A Frank Statement to \\ Cigarette Smokers}

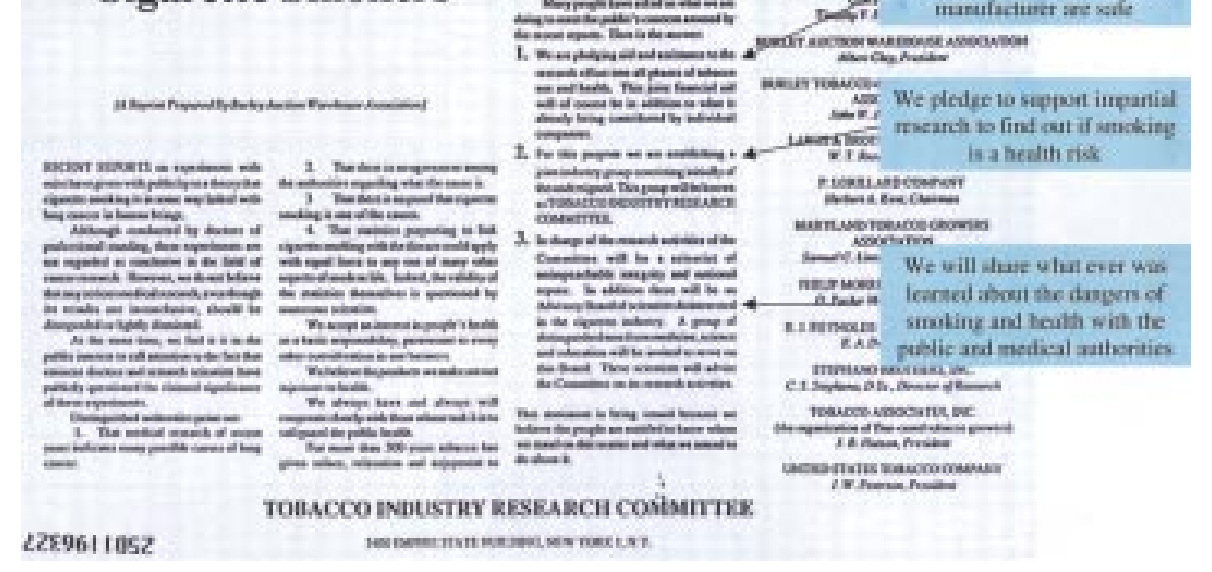

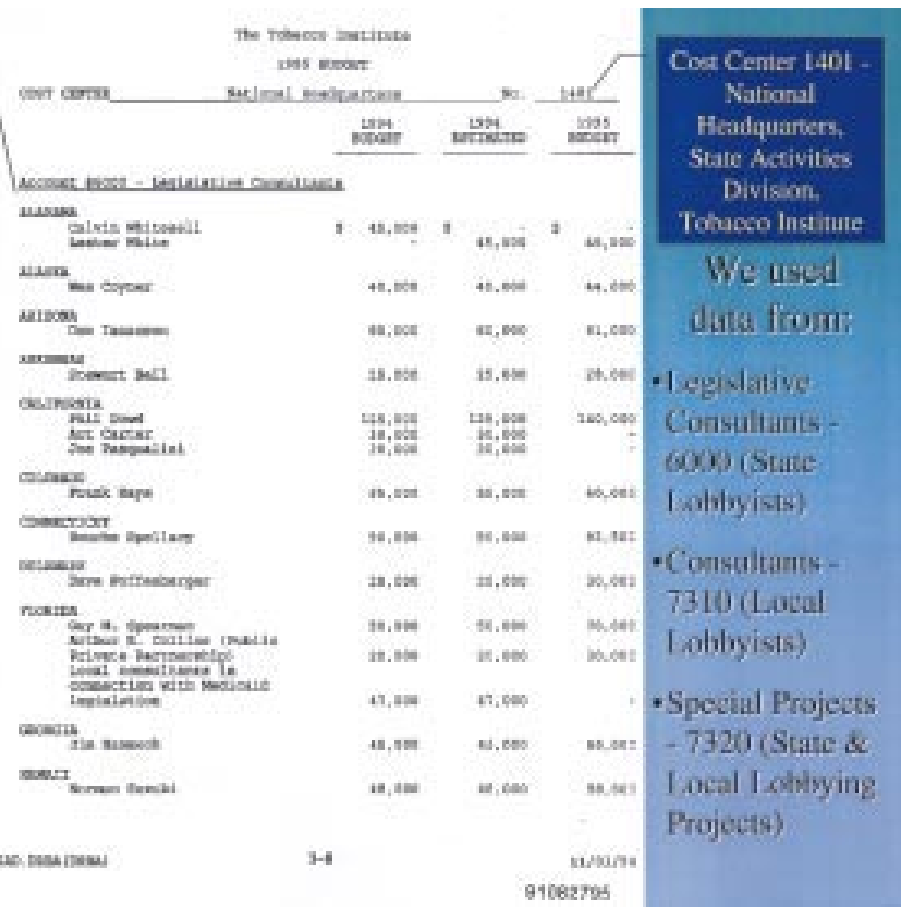

